\title{
Crystallization of Eclogite and Pyroxenite Magmas in the Diamond Depth Facies: Evidence from Garnet-Clinopyroxene Association
}

Marakushev, A.A., and Bobrov, A.V.

Geological Faculty, Moscow State University, Vorob'yovy Gory, Moscow 119899, Russia

Comparison of clinopyroxenes from the inclusions in diamonds of pyroxenite (I) and eclogite (II) types and deep-seated rocks (garnet pyroxenite, eclogite) from kimberlites, including their diamondbearing varieties, shows the specific features of the inclusions in diamonds. The known analyses of clinopyroxenes included in diamond crystals are compared with our actual material on xenoliths of diamond-bearing garnet clinopyroxenites (I) and eclogites (II) of the Udachnaya pipe. The first ones are usually enriched in iron relatively to clinopyroxenes from eclogite and pyroxenite xenoliths (Figure 1). This difference is explained by a complex evolution of diamondiferous magma and a polyfacial character of diamond-bearing rocks (Marakushev et al., 1994). The first stage of magma crystallization occurred within the field of diamond stability at a pressure of 40-60 kbar, where diamond, K-rich clinopyroxene, and Na-rich garnet were formed. Final consolidation of diamondiferous melts took place far beyond the area of diamond crystallization, after the intrusion of magma onto the higher levels of mantle and the Earth crust.

The stage of deep crystallization is clearly reflected in large porphyric garnet crystals which are abundant in eclogite and pyroxenite xenoliths from kimberlitic pipes. Crystallization of garnet, which concentrates iron, causes the depletion of magma with this element and relative enrichment of garnet and clinopyroxene with magnesium. This is proved by zonation of garnet porphyric crystals in eclogite (Figure 2, Table 1).

Table 1: Composition Profile Across the Zoned Garnet Crystal (a Diameter of $3 \mathrm{~mm}$ ) of U31 Eclogite from the Udachnaya Pipe

\begin{tabular}{l|c|c|c|c|c|c|c|c|c|c|c}
\hline & $\mathrm{SiO}_{2}$ & $\mathrm{TiO}_{2}$ & $\mathrm{Al}_{2} \mathrm{O}_{3}$ & $\mathrm{Cr}_{2} \mathrm{O}_{3}$ & $\mathrm{FeO}$ & $\mathrm{MnO}$ & $\mathrm{MgO}$ & $\mathrm{CaO}$ & $\mathrm{Na}_{2} \mathrm{O}$ & Total & $\mathrm{Fe \#}$ \\
\hline 1Core & 40.95 & 0.34 & 22.54 & - & 16.59 & 0.35 & 13.00 & 5.87 & 0.24 & 99.88 & 41.72 \\
2 & 40.86 & 0.53 & 22.56 & - & 15.76 & 0.29 & 14.68 & 4.93 & 0.33 & 99.94 & 37.56 \\
3 & 41.15 & 0.52 & 22.77 & - & 14.63 & 0.26 & 16.36 & 4.04 & 0.19 & 99.92 & 33.38 \\
4 & 41.47 & 0.59 & 22.48 & 0.16 & 12.65 & 0.25 & 17.40 & 4.67 & 0.22 & 99.89 & 28.95 \\
5 & 41.79 & 0.60 & 22.79 & 0.19 & 11.57 & 0.20 & 18.15 & 4.42 & 0.24 & 99.95 & 26.32 \\
6Edge & 42.09 & 0.59 & 22.75 & 0.41 & 9.15 & 0.35 & 19.59 & 4.90 & - & 99.83 & 20.73 \\
\hline
\end{tabular}

The relative enrichment of inclusions in diamond with Fe (both garnet [gr] and clinopyroxene [px]) in comparison with minerals of the host eclogite and garnet clinopyroxenite was reported by V.S.Sobolev with co-authors (1972) for the first time (Figure 2).

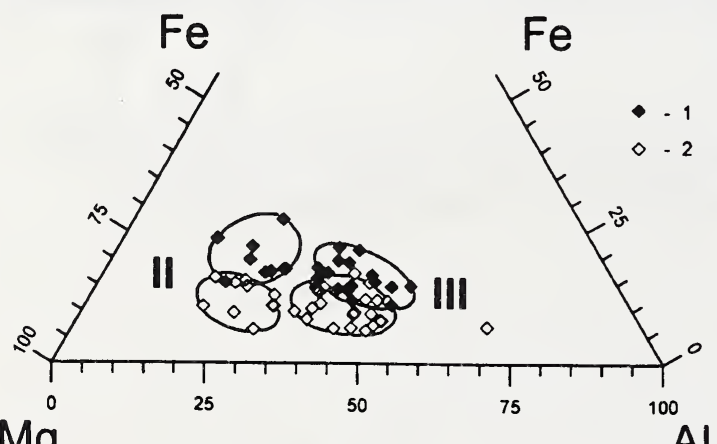

Figure 1. Composition of clinopyroxenes (1) included in diamonds and (2) from diamondbearing garnet pyroxenites (II) and eclogites (III) from the Udachnaya pipe. 
The compositions of the minerals from this M46 diamond-bearing eclogite are the following: [gr] $-\mathrm{Na}_{0.022} \mathrm{Ca}_{0.655} \mathrm{Mg}_{1.007} \mathrm{Mn}_{0.031} \mathrm{Fe}_{1.310} \mathrm{Cr}_{0.002} \mathrm{Al}_{1.947} \mathrm{Ti}_{0.022} \mathrm{Si}_{3.004} \mathrm{O}_{12}$ (inclusion in diamond);

$\mathrm{Na}_{0.023} \mathrm{Ca}_{0.693} \mathrm{Mg}_{1.108} \mathrm{Mn}_{0.023} \mathrm{Fe}_{1.186} \mathrm{Cr}_{0.004} \mathrm{Al}_{1.925} \mathrm{Ti}_{0.023} \mathrm{Si}_{3.015} \mathrm{O}_{12}$ (garnet of eclogite);

$[\mathrm{px}]-\mathrm{K}_{0.013} \mathrm{Na}_{0.465} \mathrm{Ca}_{0.503} \mathrm{Mg}_{0.480} \mathrm{Mn}_{0.002} \mathrm{Fe}_{0.148} \mathrm{Cr}_{0.002} \mathrm{Al}_{0.413} \mathrm{Ti}_{0.013} \mathrm{Si}_{1.961} \mathrm{O}_{6}$ (inclusion in diamond);

$\mathrm{K}_{0.005} \mathrm{Na}_{0.476} \mathrm{Ca}_{0.489} \mathrm{Mg}_{0.480} \mathrm{Mn}_{0.002} \mathrm{Fe}_{0.134} \mathrm{Cr}_{0.002} \mathrm{Al}_{0.398} \mathrm{Ti}_{0.015} \mathrm{Si}_{1.999} \mathrm{O}_{6}$ (pyroxene of eclogite).

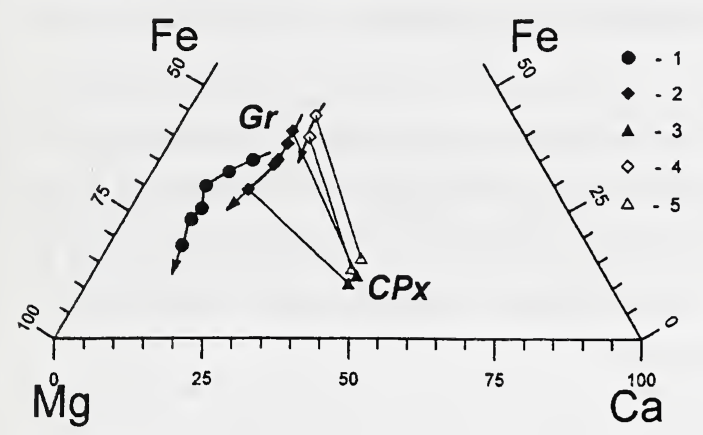

Figure 2. Evolution of garnet $(1,3,5)$ and clinopyroxene $(2,4)$ compositions from diamondbearing rocks. 1-porphyric garnet grain from diamond-bearing eclogite of the Udachnaya pipe; 2,3-inclusions in different zones of diamond crystal from the Mir pipe (Bulanova et al., 1993); 4,5-inclusions in diamond and minerals of host eclogite from the Mir pipe. (Sobolev et al., 1972).

This regularity was also proved by studies of inclusions in diamond crystals along the zones of their growth by G.P.Bulanova with co-authors (1993). These inclusions were captured on the different stages of diamond growth. In most cases an increase of $\mathrm{Mg}$ contents and a decrease of $\mathrm{Fe}$ contents in garnets and clinopyroxenes is observed in the outer parts in comparison with the inner parts of diamond crystals. Thus, clinopyroxenes from the zoned diamond (1168) have the following compositions (wt \%): $\mathrm{SiO}_{2}=54.30 ; \mathrm{TiO}_{2}=1.23 ; \mathrm{Al}_{2} \mathrm{O}_{3}=3.39 ; \mathrm{Cr}_{2} \mathrm{O}_{3}=0.06 ; \mathrm{FeO}=10.97 ; \mathrm{MnO}=0.12$; $\mathrm{MgO}=10.35 ; \mathrm{CaO}=16.50 ; \mathrm{Na}_{2} \mathrm{O}=3.15 ; \mathrm{K}_{2} \mathrm{O}=0.28 ;$ total $=100.35$ (the inner part of the diamond crystal), and $\mathrm{SiO}_{2}=55.40 ; \mathrm{TiO}_{2}=0.72 ; \mathrm{Al}_{2} \mathrm{O}_{3}=9.46 ; \mathrm{Cr}_{2} \mathrm{O}_{3}=0.15 ; \mathrm{FeO}=5.85 ; \mathrm{MnO}=0.04 ; \mathrm{MgO}=9.71$; $\mathrm{CaO}=11.96 ; \mathrm{Na}_{2} \mathrm{O}=5.44 ; \mathrm{K}_{2} \mathrm{O}=0.22$; total $=98.93$ (the outer part of the diamond crystal). The described relations show that clinopyroxene from the outer part of the diamond crystal is similar to pyroxenes from eclogite xenoliths. The range of zonation provides information on the crystallization differentiation of the eclogite and pyroxenite melts during their crystallization within the field of diamond stability and, then, beyond it.

Garnet-clinopyroxene parageneses in diamonds crystallize within a wide temperature range (from 1000 to $1300^{\circ} \mathrm{C}$ ) estimated by the methodics described in (Nikitina, 1993) at a pressure of $50 \mathrm{kbar}$.

Table 2: Garnet-Clinopyroxene Associations Included in Diamond Crystals and Temperatures of Their Crystallization ( $\mathrm{P}=50 \mathrm{kbar})$

\begin{tabular}{|c|c|c|c|}
\hline & Formula of the mineral (Gr-garnet; $\mathrm{CPx}$-clinopyroxene) & $\mathrm{T}^{\circ} \mathrm{C}$ & Reference \\
\hline 1 & $\begin{array}{l}\mathrm{Gr}: \mathrm{Na}_{0.036} \mathrm{Ca}_{0.797} \mathrm{Mg}_{0.910} \mathrm{Mn}_{0.025} \mathrm{Fe}_{1.282} \mathrm{Al}_{1.861} \mathrm{Ti}_{0.071} \mathrm{Si}_{3.014} \mathrm{O}_{12} \\
\mathrm{CPx}: \mathrm{K}_{0.002} \mathrm{Na}_{0.254} \mathrm{Ca}_{0.610} \mathrm{Mg}_{0.543} \mathrm{Mn}_{0.003} \mathrm{Fe}_{0.306} \mathrm{Al}_{0.271} \mathrm{Ti}_{0.005} \mathrm{Si}_{2.003} \mathrm{O}_{6}\end{array}$ & 1265 & $\begin{array}{l}\text { Sobolev et al., } \\
1983\end{array}$ \\
\hline 2 & $\begin{array}{l}\mathrm{Gr}: \mathrm{Na}_{0.028} \mathrm{Ca}_{0.685} \mathrm{Mg}_{1.168} \mathrm{Mn}_{0.022} \mathrm{Fe}_{1.210} \mathrm{Cr}_{0.002} \mathrm{Al}_{1.803} \mathrm{Ti}_{0.070} \mathrm{Si}_{3.007} \mathrm{O}_{12} \\
\mathrm{CPx}: \mathrm{K}_{0.006} \mathrm{Na}_{0.207} \mathrm{Ca}_{0.673} \mathrm{Mg}_{0.675} \mathrm{Mn}_{0.002} \mathrm{Fe}_{0.262} \mathrm{Al}_{0.170} \mathrm{Ti}_{0.007} \mathrm{Si}_{1.995} \mathrm{O}_{6}\end{array}$ & 1191 & $\begin{array}{l}\text { Sobolev et al., } \\
1983\end{array}$ \\
\hline 3 & $\begin{array}{l}\mathrm{Gr}: \mathrm{Na}_{0.022} \mathrm{Ca}_{0.662} \mathrm{Mg}_{1.193} \mathrm{Mn}_{0.016} \mathrm{Fe}_{1.149} \mathrm{Cr}_{0.004} \mathrm{Al}_{1.940} \mathrm{Ti}_{0.050} \mathrm{Si}_{2.961} \mathrm{O}_{12} \\
\mathrm{CPx}: \\
\mathrm{K}_{0.012} \mathrm{Na}_{0.340} \mathrm{Ca}_{0.535} \mathrm{Mg}_{0.546} \mathrm{Mn}_{0.001} \mathrm{Fe}_{0.199} \mathrm{Cr}_{0.002} \mathrm{Al}_{0.372} \mathrm{Ti}_{0.021} \mathrm{Si}_{1.969} \mathrm{O}_{6}\end{array}$ & 1151 & $\begin{array}{l}\text { Gurney et al., } \\
1985\end{array}$ \\
\hline 4 & $\begin{array}{l}\mathrm{Gr}: \mathrm{Na}_{0.015} \mathrm{Ca}_{0.447} \mathrm{Mg}_{1.388} \mathrm{Mn}_{0.021} \mathrm{Fe}_{1.143} \mathrm{Cr}_{0.004} \mathrm{Al}_{1.899} \mathrm{Ti}_{0.020} \mathrm{Si}_{3.060} \mathrm{O}_{12} \\
\mathrm{CPx}: \mathrm{K}_{0.010} \mathrm{Na}_{0.306} \mathrm{Ca}_{0.566} \mathrm{Mg}_{0.608} \mathrm{Mn}_{0.002} \mathrm{Fe}_{0.192} \mathrm{Al}_{0.297} \mathrm{Ti}_{0.013} \mathrm{Si}_{2.002} \mathrm{O}_{6}\end{array}$ & 1100 & $\begin{array}{l}\text { Sobolev et al., } \\
1983\end{array}$ \\
\hline 5 & $\begin{array}{l}\mathrm{Gr}: \mathrm{Na}_{0.023} \mathrm{Ca}_{0.243} \mathrm{Mg}_{1.881} \mathrm{Mn}_{0.017} \mathrm{Fe}_{0.831} \mathrm{Cr}_{0.006} \mathrm{Al}_{1.983} \mathrm{Ti}_{0.024} \mathrm{Si}_{2.988} \mathrm{O}_{12} \\
\mathrm{CPx}: \\
\mathrm{K}_{0.003} \mathrm{Na}_{0.336} \mathrm{Ca}_{0.383} \mathrm{Mg}_{0.765} \mathrm{Mn}_{0.002} \mathrm{Fe}_{0.188} \mathrm{Cr}_{0.002} \mathrm{Al}_{0.346} \mathrm{Ti}_{0.013} \mathrm{Si}_{1.958} \mathrm{O}_{6}\end{array}$ & 998 & $\begin{array}{l}\text { Gurney et al., } \\
1985\end{array}$ \\
\hline
\end{tabular}


A decrease of a temperature of garnet and clinopyroxene joint crystallization was caused by an increase of the $\mathrm{H}_{2} \mathrm{O}$-component concentration (and its partial pressure) in fluids as a result of disproportion chemical reactions $\left(\mathrm{H}_{2}+\mathrm{CO}=\mathrm{C}+\mathrm{H}_{2} \mathrm{O}, \mathrm{CH}_{4}+2 \mathrm{CO}=3 \mathrm{C}+2 \mathrm{H}_{2} \mathrm{O}\right.$, and the like). The flows of carbon-hydrogen fluids from the liquid core of the Earth (plumes) are supposed to be the source of $\mathrm{H}_{2} \mathrm{O}$ in magmatic chambers of diamondiferous mantle (Marakushev, 1992). The finds of $\mathrm{H}_{2} \mathrm{O}-$ rich fluid inclusions (up to $80 \% \mathrm{H}_{2} \mathrm{O}$ ) in natural diamonds (Melton, Giardini, 1974; Bulanova et al., 1993) prove this point of view.

Thus, garnet-clinopyroxene association in magmatic chambers of the diamond depth facies is a

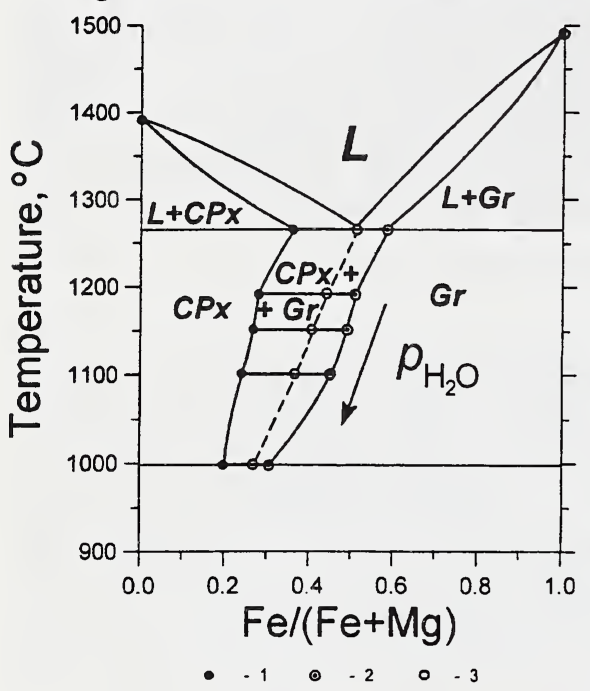
cotectic. Its temperature decreases with an increase of partial pressure of $\mathrm{H}_{2} \mathrm{O}$ in fluids. Crystallization of garnet results in rise of $\mathrm{Mg}$ content in melts and "reversed" zonation of clinopyroxene and garnet grains, typical for eclogite and garnet clinopyroxenite xenoliths in kimberlite pipes.

Thermodynamic estimations resulted in the plotting of the scheme of eclogite magma crystallization within the diamond depth facies (Figure 3 ). This diagram reflects the compositional variations of garnets and clinopyroxenes included in the diamond crystals along the zones of growth (Bulanova et al., 1993). According to the scheme, crystallization of magnesium magma begins with clinopyroxene which leads to an increase of Fe contents in melt and enrichment of clinopyroxene with this element. In the opposite case (in ferruginous melts), crystallization begins with garnet. This leads to

Figure 3. Scheme of eclogite magma an increase of $\mathrm{Mg}$ content in melt and garnets to the rims crystallization in the diamond depth of diamond crystals. Joint crystallization of garnet and facies $(\mathrm{P}=50 \mathrm{kbar}) .1-3$-compositions of clinopyroxene results in increase of $\mathrm{Mg}$ contents in both phases: 1-clinopyroxene; 2-garnet; 3- minerals, because garnet predominates over residual melt (supposed composition).

\section{References}

clinopyroxene in eutectic compositions quantitatively.

Bulanova, G. P., Barashkov, Yu. P., Tal'nikova, S. B., and Smelova, G. B., 1993, Natural diamondgenetic aspects, Novosibirsk: Nauka, 168 p (in Russian).

Gurney, J. J., Harris, J. W., Rickard, R. S., and Moore, R. O., 1985, Premier mine diamond inclusions: Trans. Geol. Soc. South Africa, Vol. 88, p. 301-310.

Marakushev, A. A., 1992, Origin of the Earth and the other planets of the solar system, Moscow: Nauka, 208 p (in Russian).

Marakushev, A. A., Cherenkova, A. F., et al., 1994, Polyfacial character of diamondiferous rocks in kimberlite and lamproite pipes: Dokl. Akad. Nauk, vol. 337, no. 4, p. 490-493 (in Russian).

Melton, C. E., and Giardini, A. A., 1974, The composition and significance of gaseous inclusions in natural diamonds from Africa and Brazil: Am. Miner., vol. 59, p. 775-782.

Nikitina, L. P., 1993, Concordant system of thermometers and barometers for basic and ultrabasic rocks and reconstruction of thermal regimes in mantle on the basis of xenoliths in kimberlites: Zap. Vses. Mineral. O-va, no. 5, p. 6-19 (in Russian).

Sobolev, N. V., Efimova, E. S, et al., 1983, Eclogite paragenesis of diamonds from Mir kimberlite pipe: Mantle xenoliths and problem of ultrabasite magma, Novosibirsk, p. 4-16 (in Russian).

Sobolev, V. S., Sobolev, N. V., and Lavrent'ev, Yu. G., 1972, Inclusions in diamond from diamondiferous eclogite: Dokl. Akad. Nauk, vol. 207, no. 1, p. 164-166 (in Russian). 